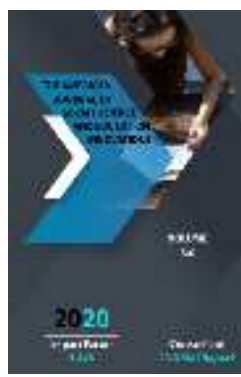

\title{
Contemporary Art Is A Factor For Developing Democratic Thinking, Forming A Strong Citizen Position
}

\author{
Marufboev Bakhtiyor Sherbekovich \\ Senior Lecturer, Department Of Social Sciences, Pedagogy And Vocational Education, \\ National Institute Of Fine Arts And Design Named After Kamoliddin Bekhzod, Uzbekistan
}

\begin{abstract}
Journal Website: http://usajournalshub.c om/index,php/tajssei

Copyright: Original content from this work may be used under the terms of the creative commons attributes 4.0 licence.
\end{abstract}

\section{ABSTRACT}

For our country, which has entered a new path of development, it is important to have openness, transparency, innovative approach to all issues, not to be indifferent to the ongoing reforms, the formation of a strong civic position in people. An important factor in achieving this is the development of modern art (contemporary art), which is the art of a democratic, post-democratic society.

\section{KEYWORDS}

Contemporary art, democratic thinking, freedom, transparency, civil position, innovative approach.

\section{INTRODUCTION}

Art is such a thing that it gathers into a single picture based on a certain idea with artistic paints the events that people imagine, experience, observe in life in different situations and situations. When the spectator observes this, the events of the work evoke thoughts such as a certain being, space, time, human life, eternity, destiny, prophecy of the future, while any picture reflected in it evokes fear, sadness, depression, amazement, joy, contentment, enthusiasm, it will be enough to arouse feelings like pride, to excite him.
According to Aristotle, art evokes emotions in a person, resulting in a state of catharsis.

As we know, contemporary art has the nature of modernism, postmodernism, and it is a mixture of many art forms and genres. This can be seen when looking at different forms of contemporary art. Today, it is difficult to find art forms that have not been penetrated by the spirit of modernity. Whether it's the art of film, or theater, music, dance, and of course they are all fine arts. 
Although modern art is not only classical art, but also different form of art, formed on the basis of genres, it has a number of distinctive aspects. In particular, it does not fall into a definite pattern, knows no boundaries, diversity, in a sense, a "retreat" from the norms of art established over the years, a creative approach to reality. Also, one of its most important aspects is that the created works are not only a rational artistic expression of reality, but also an expression of unconsciousness, subconscious, mental and emotional states. It can be said that conceptual art may not always be goaloriented. Therefore, at a glance, its essence cannot be fully understood. This means that each spectator focuses on getting something that is not molded for him or her.

If we look at the history of development of modern art, we can see that it was formed side by side with the processes of science, technology, industry, market economy relations, as well as active democratic reforms, the creation of the foundations of civil society. This is probably why creativity, freedom, not falling into a mold, in a word, the democratic spirit is paramount.

The works in this "mold" are based primarily on the primacy of universal values. It focuses more on issues such as freedom, equality, justice, peace, pluralism, friendship, nature conservation, human relations, their thoughts and feelings. Unfortunately, in many cases it seems to us only the drawback of conceptual art. He was seen as a propagandist of "popular culture" and "consumer culture" and exaggerated his "rebelliousness", provocative nature, fear of infiltrating the individual Western spirit, alienation of inexperienced spectators from art. Because we know this art more in the spirit of the West. As a result, we rarely observe its development in us, even if it exists, and the manifestation of nationalcultural identity in its nature.

MATERIALS AND METHODS
This conceptual creation differs from traditional art forms and can be said to have a unique advantage - the ability to express any idea, thought or attitude through infinite artistic, expressive means and using a combination of different types of art, scientific achievements. He does not reject national identity, as some have expressed concern, but also absorbs it and uses it where necessary in order to express his idea.

Also, formal conceptual art requires a certain preparation, a broad outlook, not only from the creator, but also from the audience. The reason is that the idea set for the project by the creator to amaze the audience is reinterpreted by applying certain complex elements. But this kind of art should not be understood as just that, as some point out. Experts admit that in fact this is a more complicated task than copying realism. After all, as much as conceptual art uses art forms and scientific achievements in its expression, it can also serve as a food for other types of art. Because when we look at the work of the representatives of this direction, we can see that most of them are sufficiently aware of today's scientific achievements and use them effectively. For example, if you look at the activities of conceptual art in the West, such as optical art, performance, cyber art, virtual art, video art, neofuturism, installation, bioart, it is not just a product of human creativity.

It is possible to be sure that the latest innovations of science, which is the locomotive of the society, the innovative, creative approach, are the basis of its success. Works of art of this kind transform the spectator's inner world and experiences in a good way, stirring his emotions, which is impossible to achieve without a broad worldview, philosophical, psychological and political views. After all, modern art is characterized by conceptuality, project vision, innovation, communication, and reliance on technology. It can also be seen that it is not just a means of cultural leisure that satisfies aesthetic needs, but that its 
mission to raise society's social, global problems of humanity, to address it by bringing it to the attention of the general public, is no less than traditional art.

We have listed above a number of important aspects of contemporary art. In other words, due to the attention to this art, the development of manufacturing, industrial and service sectors of the region can also be achieved. When we studied the experience of its development, we were struck by the missions of the Museum of Modern Art in Perm, Russia, which has achieved certain successes in this area. In particular, the museum's main mission is to "improve the quality of life of citizens", "create a creative environment", "shape and develop the image of the city", "establish international cultural integration" and "contribute to the economic development of the region" announced [1]. It seems that its effect may be greater than we thought.

There is also the view that conceptual art usually belongs only to elites who can understand acute social problems. If the locomotives of today's postindustrial society, the creators are mainly advanced knowledge, creative,

Given the fact that such "elites" are entrepreneurs and innovators with innovative ideas, it is possible to draw their attention to the changes taking place in the country, to new reforms through innovation in the conceptual arts, creativity. This means capital for entrepreneurs, investment in the economy. Its role is especially important in the development of tourism. After all, it is emphasized that no field of art and sports can make the country famous all at once. Dissatisfaction with the application of democratic principles is the first factor, as exemplified by the fact that the electoral and electoral processes, which are considered to be one of its most important principles, have caused many protests among the population today. Its outcome depends not so much on a worthy candidate in a truly healthy competitive environment, but on how successful the PR campaign is.

In some sources, conceptual art is even recognized as the art of a post-democratic society [2]. It is well known that at the beginning of the 2oth century, three major ideologies in the world were in competition with each other. These are fascism, liberal democracy and communism. First of all, fascism, and by the end of the 1980s, communism also left the world stage. As a result, only "monopoly" of liberal views, democratic processes and principles has survived. Since then, the idea of recognizing the primacy of democratic principles in the reform of governance and the political system, the full provision of human rights, freedoms and interests, and the establishment of social justice in society has become absolute. But following the practice of applying democratic principles in recent times, one can see that the world community, no matter how attractive it may seem, is dissatisfied with the idea of democracy.

The second factor has to do with the fact that revolutionary advances in information technology and biotechnology are creating problems that our minds will never solve. Indeed, the co-development of biotechnology with information technology could lead to the loss of billions of jobs in the near future, and the importance of biotechnology products could undermine human dignity and undermine the values of "freedom" and "equality" that underpin democracy. This is because big data algorithms can form a digital dictatorship, which can lead to the concentration of power in the hands of a small elite that can make the most of these opportunities. As a result, most people suffer not from exploitation, but even worse - from becoming useless beings who cannot create a useful blessing [3].

RESULT AND DISCUSSION 
As a solution to this problem, scholars consider the development of postdemocratic processes, ie direct influence on political processes, the expansion of the practice of self-government, public control, the development of elements of civil society to be a priority. Only then will the principles of democracy become a factor in ensuring social justice. This may reduce the factor that in the future the product of scientific achievements will outweigh human value.

This practice has begun to work in a sense in developed countries. But it only works when it is fully effective, when most people understand this, when self-management skills are formed. Only then will the relationship between the state and society be further strengthened, and giving in to the feelings of the existing problems as we see them today will lead to the formation of a culture of conscious, legal resolution, not in the form of various protests. Post-democratic art plays an important role in the acceleration of these processes, in the formation of a culture of self-government, a strong civic position in people. After all, art is not only a great force that evokes emotions, but also can give people different motivations.

In the context of Uzbekistan's current development strategy, in which friendship and cooperation with the world community, freedom of speech, diversity of opinion, ie the desire to implement the principles of an open society, the inculcation of the spirit of modernity in art can be considered today's demand. After all, modern art, as noted above, carries a great social burden, it is important to cover the ongoing programs, to reach the masses, to understand the ongoing reforms, to make it feel in the heart. Because we can not say that every citizen is sufficiently aware of today's changes, fully understands them and is able to apply them in their work. For example, today's openness policy reflects the long-standing problems in our society, when not only the population, but also certain leaders do not understand the essence of the reforms, when there are many conflicts with the people in the region under his leadership. can be seen in the lack of creativity in execution.

The first factor of such problems is the lack of democratic thinking in people, the ineffectiveness of non-governmental organizations, self-government institutions in the country and the lack of a strong civic position in the population. The second aspect is related to the lack of creativity in all spheres of the country, the lack of an innovative approach to the problem, a critical approach to their work. Here, too, conceptual art, a product of democratic, post-democratic thinking, can have a positive impact.

In addition, we have tasks such as the development of economic spheres, attracting investment to the country, developing the service sector, making tourism the most advanced sector that reflects the country's attractiveness. In our view, it is important today to pay more attention than ever to the development of conceptual art, to reconsider the work of museums in this context, to train professional curators who will play an important role in the success of art projects.

\section{CONCLUSION}

From the above, it can be concluded that "modern art" is a demand of today, it has a pluralistic character, like today's colorful views. It serves to form in the audience a creative approach to reality, as well as the development of "democratic", "postdemocratic" thinking, the development of a culture of self-government and the formation of a strong civic position in the population, especially among young people.

\section{REFERENCES}

1. https://ru.wikipedia.org/wiki/Музей_
современного_искусства_(Пермь)
https://ru.wikipedia.org/wiki/Соврем
eнное_искусство 
The American Journal of Social Science and Education Innovations (ISSN - 2689-100x)

Published: November 30, 2020 | Pages: 557-561

ACT FACTOR

Doi: https://doi.org/10.37547/tajssei/Volumeo2Issue11-96

2020: $5 \cdot 525$

3. Harari Yu.N. 21 lessons for the XXI

century. Sindbad, 2018. St. $13 / /$

https://avidreaders.ru/book/21-urok-

dlya-xxi-veka.html 